\title{
Waste management in the city of Shah Alam, Malaysia
}

\author{
D. B. Omar \\ Faculty of Architecture, Planning and Surveying, \\ Universiti Teknologi MARA 40450 Shah Alam, Malaysia \\ Nazrul Hisham bin Osman City Council of Shah Alam 40000 Malaysia
}

\begin{abstract}
Malaysia has been undergoing rather rapid urbanisation since the beginning of the $20^{\text {th }}$ century. The level of urbanisation increased from 55.1 per cent in 1995 to 61.8 per cent in 2000,63 per cent in 2005 and is expected to increase to 63.8 by 2010 . The total population of Malaysia was 26.75 million in 2005 and is expected to increase to 28.96 million by 2010 . This increase leads to more solid waste. The Klang Valley is the most urbanised region with 45 per cent of Malaysian urban centres being located here. The city of Shah Alam is one of the major centres in the Klang Valley and is a developing new town. Solid waste management is a major problem in the city of Shah Alam and new strategies are needed which aim at involving all citizens and achieving a sustainable environment. The City Council of Shah Alam requires waste compositional information at the local level to plan, implement and monitor waste management schemes that will enable them to meet their contribution to the national targets. This paper will discuss the current situation in the city of Shah Alam and the National Strategic Plan for Solid Waste Management.
\end{abstract}

Keywords: urbanisation, population, solid waste management, citizens, sustainable environment.

\section{Introduction}

Malaysia is now at the mid-point of its journey towards becoming a developed country by 2020 . It has been undergoing rather rapid urbanisation since the beginning of the $20^{\text {th }}$ century. The level of urbanisation increased from 55.1 per cent in 1995 to 63 per cent in 2005 and is expected to increase to 63.8 by 2010 . 
The total population was 26.75 million in 2005 and is expected to increase to 28.96 million by 2010. This increase leads to more solid waste. Among the issues and challenges of solid waste management are the increased rate of urbanisation that leads to increased waste generation, the financial constraint faced by some local authorities, lack of technical skills for special waste management, lack of public awareness and public participation, illegal dumping and increased complexity of waste composition.

The Klang Valley is the most urbanised region with 45 per cent of the Malaysian urban centres being located here. There is no official designation of the boundaries that make up the Klang Valley but it is comprised of the following areas and their corresponding 10 local authorities including Kuala Lumpur City Hall, the Putrajaya Corporation, Shah Alam City Council, Petaling Jaya City Council, Subang Jaya City Council, Klang Municipal Council, Selayang Municipal Council, Ampang Jaya Municipal Council, Kajang Municipal Council and Sepang Municipal Council. In 2006 the population was estimated at 6.5 million.

The city of Shah Alam is one of the main urban centres with a population of 584,340 in 2006 .

\section{Solid waste management in Malaysia}

The Parliament of Malaysia approved the Solid Waste and Public Cleansing Management Act 2007 in July 2007. The National Solid Waste Department together with the Solid Waste Management Corporation were established under the Ministry of Housing and Local Government to give the Federal Government the power to take back solid waste management and public cleansing from the local councils and state governments. They were to undertake policy formulation, planning and management of solid waste including financial management [1].

As stated in the Ninth Malaysia Plan (2006-2020) as a need to deal with great changes in the global environment one of the National Missions is to improve the standard and sustainability of quality of life among the people [2]. In line with this the government adopted the National Strategic Plan for Solid Waste Management (NSPSWM) to ensure integrated and sustainable solid waste management. The policy has two aims:

i) to create a solid waste management system that is holistic, integrated, cost effective, sustainable and acceptable to the community, that emphasises the conservation of the environment, selection of affordable technology and ensures public health,

ii) to implement solid waste management based on the waste hierarchy, which emphasizes waste minimisation through $3 \mathrm{R}$, intermediate treatment and final disposal.

Quality infrastructure and necessary facilities will continue to be rolled out throughout the country for the benefit of the people. To underscore the importance of collaboration and collective effort, the government has chosen Together Towards Excellence, Glory and Distinction as the theme of the Ninth 
Plan. It was formulated after extensive consultations with all sections of society throughout the country [3].

Under the current framework the Ministry of Housing and Local Government represents Federal Government to provide local councils with technical and financial assistance; the State Government to assist in the form of land requirement, and Local Government to provide solid waste management services within their areas [4].

Prior to that as stated in the Local Government Act, 1976 (Act 171) local authorities undertook various obligatory and discretionary activities and providing services to the urban population. These included the provision of solid waste management services as well as the provision of public amenities. The collection and disposal of municipal solid waste was carried out by concession companies, operators or the respective local authorities. In order to enhance the quality of the environment as part of Vision 2020, the Government initiated the privatisation of urban solid waste disposal in 1995. The objective was to provide an integrated, well-planned, well-managed, efficient and effective, technologically advanced solid waste management system. The thrust of the system is on waste reduction and the use of technology to recover resources from waste (recycling, composting, incineration etc.), thereby minimising the need for landfill. The monthly payment was based on actual expenses by the local authority in the year prior to the take over [5].

In 2000 promotion of recycling was intensified to reduce wastes generated by the general public. Greater awareness among the public on the importance of recycling through extensive recycling campaigns and activities were carried out by 97 local authorities in collaboration with the private sector and non governmental organisations (NGOs),

In 2005, 7.34 million tones of solid waste were generated in the country expected to be 30,000 tonnes per day by 2020 . Of this $45 \%$ are food waste, $24 \%$ plastic waste, $7 \%$ paper, $6 \%$ iron and glass and others [6].

\section{City of Shah Alam}

The city of Shah Alam is about 25 kilometres west of Kuala Lumpur. In 1978, it replaced Kuala Lumpur as the capital city of the state of Selangor to Kuala Lumpur's incorporation into a Federal Territory in 1974. Shah Alam was once known as Sungai Renggam and was noted for its rubber and oil palm estates. Its current name was chosen by the then state Sultan of Selangor, Sultan Salahuddin Abdul Aziz Shah after his late father Sultan Alam Shah.

Shah Alam was developed as a new town in 1960 by The Selangor State Economic Development Corporation as a state capital city. Since the $10^{\text {th }}$ October 2000 Shah Alam was declared as the city of Shah Alam. It covers an area of 290.3 kilometer square. New towns are intended to provide a more pleasant and efficient urban environment than existing towns. The ways in which the urban quality of life is influenced by planning activities at this early stage, that bring about changes in the physical reality, are of profound importance in new town development. The urban quality of life is aimed at providing useful 
insights of the contested and complex nature of concepts of developments such as community, land use distribution, rules and guidelines, places of interest, infrastructure, homes, community facilities, safety and other attributes [7].

The city of Shah Alam is well connected to other main cities in Klang Valley by highways and railways. It is also well connected to main transportation hubs such as the Kuala Lumpur International Airport (KLIA) (30 km south of the city) and KL Sentral in Kuala Lumpur and Klang Seaport. There are 3 institutions of higher learning with University Teknologi MARA has the biggest number of about 70,000 students. Shah Alam is served by 16 secondary schools, more than 20 primary schools and two vocational schools.

\section{Solid waste management in the city of Shah Alam}

As stated earlier in 1995, the Government of Malaysia initiated the privatisation of urban solid waste disposal. In 1998 Shah Alam Council and Alam Flora Sdn Bhd (AFSB) signed the solid waste management agreement with the scope covering collection, cleansing and disposal, taking over staffs, vehicles, contracts and disposal sites [8].

Among the issues raised by AFSB [9] was lack of public awareness, improper storage methods used by the community including concrete bins, rattan basket, broken pails, oil/paint drums. Some even hanged the plastic bag full of waste on trees and fences. There happened to be rampant littering even when bins are provided, illegal dumping on vacant land, back lanes and road shoulders. In some places open lorries and non-compaction vehicles were used for waste collection. These vehicles were mostly aged which caused leachate spillage and often broke down. The facilities at central collection point were not maintained and were not friendly to consumers. The locations of some bins were not proper. As for the disposal sites there were 168 sites with 161 are open sites and only 7 are sanitary landfill. It was found that $80 \%$ were at end of life and situated near waterways with inadequate infrastructure and basic amenities. This created environmental problems including inadequate/improper cover material, leachate seepage to rivers and ground water, flies and rodents and landfill gases.

Table 1: $\quad$ Solid waste collection in Shah Alam by AFSB [10].

\begin{tabular}{|l|l|l|l|}
\hline Year & $\begin{array}{l}\text { Domestic } \\
\text { Waste }\end{array}$ & $\begin{array}{l}\text { Non domestic } \\
\text { waste }\end{array}$ & Payment (RM) to AFSB \\
\hline 2002 & $46,493.47$ & $2,644.22$ & $27,735,743.32$ \\
\hline 2003 & $70,163.87$ & 2,964 & $31,212,802.75$ \\
\hline 2004 & $81,675.82$ & $3,291.24$ & $35,741,366.10$ \\
\hline 2005 & $97,324.70$ & $3,700.00$ & $42,953,846.27$ \\
\hline 2006 & $107,561.96$ & $4,000.00$ & $50,644,129.18$ \\
\hline 2007 & $130,104.72$ & $5,473.10$ & $55,000,000.00$ (estimated) \\
\hline
\end{tabular}

Table 1 shows the solid waste collected from year 2002 to 2007 for Shah Alam city. The figure for 2007 payment was estimated based on trend of 
previous years. The highest increase in domestic waste was from 2002 to 2003 that is $50.9 \%$. However the trend of increase of the following years ranged between 16 to 21 percent. The figures are as follows: 2003-04=16.4\%; 2004$05=19.2 \% ; 2005-06=10.5 \% ; 2006-07=21 \%$. There was tremendous increased of $179.8 \%$ of domestic waste from 2002 to 2007 . As for non domestic the increase was $106 \%$ from 2002 to 2007 . This is due to the increase of population in Shah Alam. AFSB received payment increased of $86.2 \%$ from 2002-2006. However based on estimated payment of RM55million for 2007 the increase in payment was $98.5 \%$ from 2002 to 2007. Wastes from Shah Alam were sent o Jeram Landfill Station.

There are six recycle centres in Shah Alam run by private companies. These centres are located in Section 7, 11, 17, 20, 28 and U19. Most of these centres open six days a week from 10 am to $5 \mathrm{pm}$. Recycle items sent in by the community are exchanged for cash. Recycle items collected are newspaper, magazines, books, cardboards, boxes, aluminium cans, metal tin, glass wares and plastic material. As to date only about $5-6 \%$ of solid waste is recycled. It was found that metal based products have the highest selling price.

Table 2: $\quad$ Data on compounds issued by the city of Shah Alam [11].

\begin{tabular}{|c|c|c|c|c|}
\hline \multirow{2}{*}{$\begin{array}{c}\text { Compound issued } \\
\text { based on activity }\end{array}$} & $\mathbf{2 0 0 3}$ & $\mathbf{2 0 0 4}$ & $\mathbf{2 0 0 5}$ & $\mathbf{2 0 0 6}$ \\
\cline { 2 - 5 } & 55 & 174 & 556 & 367 \\
\hline $\begin{array}{c}\text { Compound issued on } \\
\text { littering }\end{array}$ & 54 & 33 & 107 & 89 \\
\hline $\begin{array}{c}\text { Compound issued on } \\
\text { illegal dumping }\end{array}$ & 118 & 126 & 144 & 101 \\
\hline $\begin{array}{c}\text { Compound issued for } \\
\text { not using waste } \\
\text { bin/improper/without } \\
\text { plastic bag }\end{array}$ & & & & \\
\hline
\end{tabular}

The city council made monthly payment of RM136,666.70 to contractors for clearing the illegal dumping on vacant land, back lanes and road shoulders. These illegal wastes include old furniture, electrical goods, green waste, constructions and renovation waste. Table 2 shows the number of compounds issued by the city council based on activities. In year 2005 was the highest number of compounds issued for all the three categories. However there was some decrease in 2006, which may be due to increase of public awareness and better enforcement service provided by the city council.

\section{Proposed programmes}

Public participation and awareness are important issues in achieving the goals of the waste management system especially the $3 \mathrm{R}$ (reduce, reuse and recycle). The 
promotion of recycling was intensified since year 2000. Unfortunately, it is difficult and also takes a long period of time to make people aware of their participation. One of the pilot projects initiated by the city council was the composting of food waste from a school canteen for plant fertilizer. Food wastes, which are the major components of the solid waste, are suitable substrates for composting. Landscaping activities may use this composting due to its potential benefits, such as improving manure handling and enhancing soil fertility. It is hoped that by the full support of education systems, will make students and the new generation aware of the importance of the principles of the solid waste management system. This pilot project needs to be extended to other schools and all community. If combined with a strong education and publicity programme, the pilot project can help society become aware of the system.

The City Council of Shah Alam has been selected by Danish International Development Assistance (DANIDA) to receive appropriate funding for solid waste management initiatives implemented, involving local stakeholders and the public. The proposed project involved the development of a Civic Amenities site with estimated cost of more than RM500,000. The project is scheduled to be implemented soon. This civic amenity site is where the public can dispose of household and will be run by the city council. Solid waste management is one of five components under the DANIDA supported Environmental Cooperation Programme (2003-2009). Within the cooperation framework, the Malaysian Government and DANIDA have initiated the Solid Waste Management Component (SWMC). Through the component, the Malaysian Government and DANIDA have allocated funding for Community Based Initiatives and Education Programmes related to the Solid Waste Management [12].

In Malaysia not much has been done on the academic research of solid waste management issues. There seems to be a lack of interaction between industry and academia since there is little academic penetration into this very relevant problem area. It is suggested that more active industry involvement is required to get a beneficial exchange between academia and industry. The Federal Government should offer more funds for research and development on solid waste management.

\section{Conclusion}

In conclusion, it is too early to make a concrete assessment of the newly set up institutional structure of solid waste management in Malaysia. Reporting in the local media revealed that the move is to better manage the waste. With a better work culture among the Federal, State and Local Government and the gradual introduction of new approach into solid waste management, the service is expected to be more reliable. However, it is necessary to wait for the Ministry of Housing and Local Government implementing the new act. The real success will be measured by the quality of service and, in most cases, the quality of life and living environment it brings about for all society including city of Shah Alam residents. A master plan on solid waste minimisation at the national level will be formulated aimed at strengthening the institutional capacity of respective 
agencies as well as creating a society that is committed towards waste minimisation and achieving a recycling target of 22 per cent by 2020 .

\section{References}

[1] Nadzri Yahaya, (2007). Solid Waste Management in Malaysia, Keynote Address, Waste to Wealth, International Conference and Exhibition 2007, Kuala Lumpur.

[2] Government of Malaysia, (2005). The Ninth Malaysia Plan Report, Malaysian Government Printer, Kuala Lumpur.

[3] Government of Malaysia, (2005). The Ninth Malaysia Plan Report, Malaysian Government Printer, Kuala Lumpur.

[4] Daud Muhamad and Muhd Noor Mohd Yunus, (2007). Towards the Realization of $W 2 W$, Waste to Wealth, International Conference and Exhibition 2007, Kuala Lumpur.

[5] Sivapalan Kathiravale, Mohd Fairuz Abdul Farid, Mohd Azma. Che Mat Isa, Norasalwal Zakaria, Khaironi Mohd Takip, Rohyiza Baan, (2007). Waste Management- The Obligation and Opportunities in Malaysia, Waste to Wealth, International Conference and Exhibition 2007, Kuala Lumpur.

[6] Nadzri Yahaya, (2007). Solid Waste Management in Malaysia, Keynote Address, Waste to Wealth, International Conference and Exhibition 2007, Kuala Lumpur.

[7] Dasimah bt Omar, (2003). Urbanisation, Urban Fringe Development and the Quality of Life: Evidence from New Town Development in Peninsular Malaysia, Planning Congress, Adelaide 2003.

[8] Alam Flora Sdn Bhd, (February 2008). Official Document.

[9] Alam Flora Sdn Bhd, (2005). Solid Waste Management by Alam Flora Sdn Bhd, Waste Management Workshop 2005, Kuala Lumpur.

[10] Alam Flora Sdn Bhd, (February 2008). Official Document.

[11] City Council of Shah Alam, (2007). Annual Report 2007, City Council of Shah Alam, Malaysia.

[12] City Council of Shah Alam, (2007). Annual Report 2007, City Council of Shah Alam, Malaysia. 